\title{
PERFORMANS PRODUKSI BURUNG PUYUH BETINA (Coturnix coturnix japonica) PADA LAMA PENCAHAYAAN YANG BERBEDA
}

\author{
Febrian Rotikan, L. J. Lambey, B. Bagau, J. Laihad
}

Fakultas Peternakan Universitas Sam Ratulangi Manado, 95115

\begin{abstract}
ABSTRAK
Penelitian ini untuk mengetahui pengaruh lama pencahayaan terhadap performans produksi burung puyuh betina (Coturnix coturnix japonica) umur $3-8$ minggu telah dilaksanakan di kandang percobaan, Jurusan Ilmu Produksi Fakultas Peternakan Universitas Sam Ratulangi Manado. Sejak tanggal 25 November 2016 sampai tanggal 6 Januari 2017. Materi yang digunakan dalam penelitian ini adalah 80 ekor burung puyuh betina yang berumur 3 minggu. Rancangan yang digunakan dalam penelitian ini adalah rancangan acak lengkap (RAL) yang terdiri dari 4 perlakuan dan 5 ulangan. Perlakuan tersebut adalah tanpa penambahan cahaya sebagai kontrol yaitu (R0), penambahan cahaya selama 4 jam (R1), penambahan cahaya selama 8 jam (R2), dan penambahan cahaya selama 12 jam (R3).Variabel yang diukur adalah jumlah konsumsi pakan, umur awal bertelur, produksi telur dan bobot telur. Hasil penelitian yang diperoleh menunjukkan bahwa lama pencahayaan lampu menunjukkan pengaruh yang berbeda tidak nyata $(\mathrm{P}>0,05)$ terhadap konsumsi pakan, umur awal bertelur, produksi telur dan bobot telur. Berdasarkan hasil dan pembahasan dapat disimpulkan bahwa penambahan cahaya selama $0,4,8$ dan $12 \mathrm{jam} /$ hari tidak mempengaruhi performans produksi burung puyuh betina (Coturnix coturnix japónica).
\end{abstract}

Kata kunci: Burung Puyuh, Lama Pencahayaan, Performans

\footnotetext{
*Korespondensi (corresponding Author)

Email: lucialambey@yahoo.com
}

\begin{abstract}
PRODUCTION

PERFORMANCE OF FEMALE QUAILS (Coturnix coturnix japonica) UNDER DIFFERENT LIGTH ILLUMINATIONS. The objective of this study was to evaluate the duration effect of light illuminations on egg production performance of female quails (Coturnix coturnix japonica). Total of 80 female quails at the age of 3 weeks old were used in this study. The total of 4 birds were raised in the cage of $40 \times 30 \mathrm{~cm}$. Birds were randomly put in the cage using completely randomized design for the four treatments consisting of cage without light illumination (R0), cage with light illumination during 4 hours per day (R1), cage with light illumination during 8 hours per day (R2), and cage with light illumination during 12 hours per day (R3). Variables measured were feed consumption, age at first laying egg, egg production and egg weight. Results showed that light illumination did not significantly affect feed consumption, age at first laying egg, egg production and egg weight. Therefore, it can be concluded that production management of female quails (Coturnix coturnix japonica) did not need light illumination during 4, 8 and 12 hours per day.
\end{abstract}

Key words: Female quail, Light illuminations, Production performance 


\section{PENDAHULUAN}

Puyuh memiliki nilai ekonomi penting sebagai penghasil telur dan daging. Budidaya puyuh sudah sejak lama dilakukan oleh masyarakat. Jenis puyuh yang dipelihara dan dibudidayakan untuk dimanfaatkan telurnya adalah dari jenis Coturnix coturnix japonica karena jenis ini memiliki kemampuan bertelur yang cukup tinggi, yang mampu menghasilkan telur sekitar 250 - 300 butir telur/ekor/tahun. Burung puyuh betina sudah mulai masak kelamin pada umur 5-6 minggu.

Salah satu hal yang penting dalam pemeliharaan burung puyuh untuk produksi telur adalah tata laksana pencahayaan. Peranan cahaya secara umum diketahui dapat mempengaruhi tingkah laku unggas karena cahaya memfasilitasi unggas untuk melihat; yang artinya unggas dapat beraktivitas dan adanya reaksi hormonal di dalam tubuhnya. Cahaya yang masuk ke dalam ruangan dengan intensitas yang cukup memungkinkan unggas untuk dapat melihat lingkungan sekitar, terutama pakan dan minum.

Unggas merupakan ternak yang peka terhadap rangsangan cahaya. Pada periode starter cahaya berperan penting dalam proses pertumbuhan melalui pengaturan sekresi hormon somatotropik. Pada periode grower cahaya berperan dalam proses pendewasaan kelamin melalui pengaturan sekresi hormon melatonin. Pada periode layer, cahaya berperan dalam proses produksi melalui pengaturan sekresi hormon LH (Luteinizing Hormone) dan FSH (Follicle Stimulating Hormone) yang berperan dalam produksi oosit yang pada akhirnya menentukan produksi telur.

Salah satu aspek tatalaksana pemeliharaan burung puyuh petelur adalah pencahayaan yang dapat berpengaruh pada performans produksi. Sejauh mana lama pencahayaan dapat mempengaruhi performans produksi burung puyuh betina perlu dilakukan penelitian. Penelitian ini bertujuan untuk mengetahui pengaruh lama pencahayaan terhadap performans produksi (konsumsi pakan, umur awal bertelur, produksi telur dan bobot telur) burung puyuh betina umur $3-8$ minggu.

\section{MATERI DAN METODE PENELITIAN}

\section{Materi Penelitian}

Ternak yang digunakan dalam penelitian ini adalah burung puyuh jenis Cortunix-cortunix japonica yang berumur 3 minggu. Jumlah anak burung puyuh (DOQ) yang dipelihara sebanyak 80 ekor berjenis kelamin betina. Pakan yang digunakan dalam penelitian ini adalah pakan SP-22 yang diproduksi oleh PT. Sinta Prima Feedmill. Kandungan nutrisi pakan komersial burung puyuh yaitu protein 20- 
$22 \%$, lemak $4-7 \%$, serat kasar $6 \%$, abu $14 \%$, air $12 \%$, Ca 3,5-4,0\%, P 0,6-0,8\% dan energi bruto $3475 \mathrm{kkal} / \mathrm{kg}$. Vitamin yang digunakan adalah Vita Chicks dan Vita Stress.

Kandang yang digunakan adalah kandang sistem koloni sebanyak 20 kandang dengan ukuran panjang $40 \mathrm{~cm}$ dan lebar $30 \mathrm{~cm}$. Pada setiap kandang berisi 4 ekor burung puyuh. Peralatan yang digunakan dalam penelitian ini adalah tempat pakan, tempat minum, alat tulis, kertas label, kardus berfungsi sebagai sekat, kabel, lampu pijar dengan daya 5 watt berjumlah 20 buah, timbangan digital.

\section{Metode Penelitian}

Penelitian ini menggunakan Rancangan Acak Lengkap (RAL) menurut petunjuk Steel and Torrie (1995), yang terdiri dari 4 perlakuan dan 5 kali ulangan. Perlakuan ialah lama pencahayaan. Penambahan cahaya dilakukan mulai pukul 18.00. Perlakuan R0 tanpa penambahan cahaya lampu, perlakuan R1 penambahan cahaya selama 4 jam dari pukul 18.0022.00, perlakuan R2 penambahan cahaya selama 8 jam dari pukul 18.00-02.00, perlakuan R3 penambahan cahaya selama 12 jam dari pukul 18.00-06.00.

Model matematika yang digunakan sebagai berikut :

$\mathrm{Yij}=\mu+\alpha \mathrm{i}+\varepsilon \mathrm{ij}$

Yij : Nilai pengamatan pada pemberian cahaya lampu ke-i dan ulangan ke-j $\mu:$ Nilai rataan umum

ai : Pengaruh perlakuan pemberian cahaya ke-i

عij : Pengaruh galat percobaan pemberian cahaya ke-i pada ulangan ke-j

Puyuh dibagi menjadi 4 kelompok sesuai perlakuan, yaitu :

R0 : Tanpa penambahan cahaya

R1 : Penambahan cahaya selama 4 jam

R2 : Penambahan cahaya selama 8 jam

R3 : Penambahan cahaya selama 12 jam

\section{Prosedur Penelitian}

Sebelum digunakan dinding kandang dicat dengan kapur, selanjutnya kandang dibersihkan dari kotoran, dicuci menggunakan detergen dan disinfektan. Kandang dilengkapi dengan tempat pakan, air minum, tempat telur, dan tempat penampungan feses. Kandang baterai sebanyak 20 unit masing-masing diletakkan ditempat yang berbeda kemudian diberi nomor. Di bawah kandang dialaskan koran untuk penampungan feses dan juga untuk mempermudah pembersihan kandang.

Masing-masing kelompok puyuh dimasukkan kedalam kandang kotak yang didalamnnya telah disediakan makanan dan air minum yang telah diberikan vitastress. Pemberian vitastress dilakukan untuk menghilangkan stres setelah pindah kandang.

Pemberian pakan dan minum dilakukan sehari sekali pada pagi hari. Pakan yang digunakan dalam penelitian ini 
adalah pakan komersial, sebelum diberikan kepada ternak, pakan ditimbang masingmasing 100 gr untuk 1 kandang.

Pencatatan dilakukan pada pemberian pakan harian dan sisa pakan untuk mengetahui konsumsi pakan. Pengambilan data pada jumlah telur tiap kandang dan dilakukan penimbangan telur tiap kandang setiap hari untuk mengetahui jumlah telur dan bobot telur.

\section{Variabel yang diamati}

Variabel yang diamati selama penelitian meliputi :

1. Konsumsi Pakan (gram/ekor/hari)

Konsumsi pakan dihitung dari jumlah pakan yang dikonsumsi oleh burung puyuh selama periode pemeliharaan. Konsumsi pakan dihitung dari pakan yang diberikan kepada burung puyuh dikurangi dengan sisa pakan (Sumbawati, 1992).

2. Umur Pertama Bertelur (dewasa kelamin).

Umur awal bertelur ditandai dengan umur pertama kali burung puyuh bertelur.

3. Produksi Telur (\% Quail-day)

Dihitung berdasarkan perbandingan antara jumlah telur per hari dengan jumlah puyuh yang hidup dikali waktu kemudian dikali 100\%
(Sudrajat et al, 2014), dengan rumus:

Produksi telur $(\mathrm{PT})=$

$\frac{\text { Jumlah produksi telur (butir) }}{\text { Jumlah puyuh yang hidup (ekor) } \times \text { waktu (hari) }} \times 100 \%$

4. Berat Telur : merupakan perbandingan antara jumlah berat telur yang dihasilkan (g) dengan jumlah telur yang dihasilkan (North, 1990) atau dengan rumus sebagai berikut :

$\mathrm{BT}=\frac{\text { Jumlah berat telur yang dihasilkan }(\mathrm{g})}{\text { Jumlah telur yang dihasikan (butir) }}$

\section{Analisis Data}

Data yang diperoleh pada penelitian ini dianalisis sidik ragam (Anova) untuk mengetahui pengaruh perlakuan terhadap peubah yang diamati.

\section{HASIL DAN PEMBAHASAN}

Hasil penelitian pengaruh lama pencahayaan terhadap performans produksi burung puyuh dapat dilihat pada Tabel 2.

\section{Pengaruh Perlakuan Terhadap Konsumsi Pakan}

Pada Tabel 1 menunjukkan bahwa rataan konsumsi pakan per ekor per hari ternak puyuh selama penelitian berkisar antara 19,57 - 20,74 g/ek/hr. Kisaran ini masih sesuai dengan standar kebutuhan menurut Sunarno (2004) yang menyatakan konsumsi pakan burung puyuh umur 21 . 
Tabel 1. Rataan pengaruh penambahan cahaya terhadap konsumsi pakan, umur awal bertelur, produksi telur dan berat telur burung puyuh.

\begin{tabular}{lcccc}
\hline \multicolumn{1}{c}{ Parameter } & \multicolumn{5}{c}{ Perlakuan } \\
\hline & $\mathrm{R} 0$ & $\mathrm{R} 1$ & $\mathrm{R} 2$ & $\mathrm{R} 3$ \\
\hline Konsumsi pakan (gram) $^{\mathrm{ns}}$ & 19,57 & 19,27 & 20,02 & 19,44 \\
Umur awal bertelur (hari) $_{\text {Produksi telur (\%) }}^{\mathrm{ns}}$ & 41 & 42 & 41 & 43 \\
Berat telur (gram) $^{\mathrm{ns}}$ & 45,69 & 44,92 & 46,77 & 44,99 \\
\hline Keterangan & 11,46 & 11,05 & 11,76 & 9,11 \\
\hline
\end{tabular}

Keterangan: ns: non signifikan

sampai 55 hari sekitar 14 - 24 g/ekor/hari. Hasil analisis statistik menunjukkan bahwa penggunaan cahaya lampu selama $0,4,8$, dan 12 jam tidak menunjukkan pengaruh yang berbeda nyata $(\mathrm{P}>0.05)$ terhadap konsumsi pakan. Menurut Achmanu et al. (2011), perbedaan efisiensi pakan disebabkan karena adanya perbedaan dalam konsumsi pakan dan jumlah produksi telur. Menurut North dan Bell (1990), faktor yang mempengaruhi konsumsi pakan harian pada unggas dibagi menjadi dua kelompok. Kelompok yang berpengaruh dominan adalah suhu lingkungan. Kelompok yang berpengaruh minor adalah strain burung, berat tubuh, bobot telur harian, pertumbuhan bulu, derajat stress dan aktivitas burung. Gordon (1994) menyatakan bahwa pemberian cahaya pada unggas ditujukan agar unggas mendapatkan kesempatan untuk makan, minum serta aktivitas lainnya, selain itu cahaya juga penting dalam proses reproduksi. Pada penelitian ini ternyata cahaya tidak mempengaruhi secara nyata terhadap konsumsi pakan burung puyuh. Hal ini disebabkan karena pada ternak unggas, adanya faktor pembatas konsumsi pakan yaitu kapasitas tembolok (North and Bell, 1990). Burung puyuh yang mendapatkan cahaya lebih lama akan mempunyai kesempatan untuk mengkonsumsi pakan lebih banyak daripada yang lain, tetapi adanya faktor pembatas tersebut menyebabkan burung puyuh akan berhenti makan ketika kebutuhannya telah terpenuhi. Menurut Nuraini et al. (2012) bahwa konsumsi pakan dipengaruhi oleh beberapa faktor antara lain: umur, palatabilitas ransum, kesehatan ternak, jenis ternak, aktivitas ternak, energi ransum, tingkat produksi, kuantitas dan kualitas ransum.

\section{Pengaruh Perlakuan Terhadap Umur Awal Bertelur}

Data pada Tabel 1 menunjukkan bahwa umur pertama kali bertelur burung puyuh pada penelitian ini berkisar antara 41 
hari - 43 hari atau ada dalam kisaran 6 minggu. Hasil ini sesuai dengan pendapat Mufti (1997) bahwa burung puyuh mulai bertelur pada umur 6 minggu. Cahaya akan direspon oleh burung puyuh melalui indra penglihatan. Melalui mata cahaya dapat merangsang hipothalamus untuk menghasilkan hormon Gonadotropin dan merangsang kelenjar pituitari untuk menghasilkan FSH dan LH. Kedua hormon ini bereperan dalam proses reproduksi. Elfiandra (2007), menyatakan cahaya berfungsi dalam proses penglihatan, merangsang siklus internal dan menstimulasi pelepasan hormon, baik hormon pertumbuhan maupun hormon reproduksi. Cahaya dapat mempengaruhi perilaku dan reproduksi unggas. Gelap atau terhambatnya cahaya akan merangsang kelenjar pineal untuk memproduksi hormone melatonin, akibatnya produksi melatonin yang berlebih akan menyebabkan terhambatnya perkembangan seksual (Cockrem, 1985).

\section{Pengaruh Perlakuan Terhadap Produksi Telur}

Rataan produksi telur burung puyuh berkisar antara 44,92\% - 46,77\%. Penambahan cahaya $0,4,8$ dan 12 jam menunjukkan perbedaan yang tidak nyata. . Morris (1994) menyatakan bahwa ada hubungan antara intensitas cahaya dengan produksi telur Hal ini tidak sesuai dengan hasil penelitian ini, disebabkan karena lama penelitian untuk menghitung produksi telur sesudah dewasa kelamin hanya 2 minggu, sehingga pengaruh perlakuan tidak memberikan pengaruh yang nyata. Yasin (1988) menyatakan bahwa secara garis besar produksi burung puyuh dipengaruhi oleh beberapa faktor antara lain, genetik, ransum, kandang, temperatur, lingkungan, penyakit dan stress. Diwayani et al. (2012); Hasan et al. (2003) menyatakan bahwa burung puyuh dengan berat badan 90 sampai 100 gram akan mulai bertelur umur 35 sampai 42 hari produksi telur dipengaruhi oleh strain, umur pertama bertelur, konsumsi pakan.

\section{Pengaruh Perlakuan Terhadap Berat Telur}

Dari rataan tersebut dapat dilihat bahwa berat telur relatif sama. Hasil analisis statistik menunjukkan bahwa lama pencahayaan lampu menunjukkan pengaruh yang berbeda tidak nyata $(\mathrm{P}>0.05)$ terhadap rataan bobot telur yang dihasilkan. Hal ini berarti tidak terjadinya perbedaan respon puyuh dalam menerima rangsangan cahaya yang dapat mempengaruhi bobot telur. Song et al. (2000) menyatakan bahwa rata-rata bobot telur puyuh normal adalah $10.34 \mathrm{~g}$ per butir. Rataan bobot telur dipengaruhi oleh jenis atau tipe puyuh dan umur puyuh (Santos et al., 2011). 


\section{KESIMPULAN}

Berdasarkan hasil dan pembahasan dapat disimpulkan bahwa penambahan cahaya selama $0,4,8$ dan 12 jam/hari tidak mempengaruhi performans produksi burung puyuh betina (Coturnix coturnix japonica).

\section{DAFTAR PUSTAKA}

Achmanu, Muharlien, dan Salaby. 2011. Pengaruh lantai kandang (rapat dan renggang) dan imbangan jantan-betina terhadap konsumsi pakan, bobot telur, konversi pakan dan tebal kerabang pada burung burung puyuh. J.Ternak Tropika Vol. 12, No.2: 1-14,2011.

Cockrem, JF and BK Follett. 1985. Circadian rhythm of melatonin in the pineal gland of the Japanese quail (Coturnix coturnix japonica). Journal of Endocrinology, Vol 107, Issue 3, 317-324

Diwayani, R. M, D. Sunarti, dan W. Sarengat. 2012. Pengaruh pemberian pakan bebas pilih (Free choice feeding) terhadap performans awal peneluran burung puyuh (Coturnix-coturnix japonica). Anima Agricultural Journal, Vol. 1(1): 23-32.

Elfiandra. 2007. Pemberian warna lampu penerangan yang berbeda terhadap pertumbuhan badan ayam broiler. Skripsi. Program Studi Teknologi Produksi Ternak. Fakultas Peternakan. Isntitut Pertanian Bogor.
Gordon, S.H. 1994. Effects of day length and increasing daylength programmes on broiler welfare and performance. Word Poultry Science Journal. 50:269-282

Hasan, S. M., M. E. Mady, A. L. Cartwright, H. M. Sabri dan M. S. Mobarak. 2003. Effect of early feed restriction on reproductive performance in Japanese Quail (Coturnix-coturnix japonica). J. Poultry Sci, 82 : 1163-1169.

Morris, T. R. 1994. Lighthing for layer : what we know and we need to know. World Poultry Science Journal. 50 : 283-287

Mufti, M. 1997. Dampak foto regulasi dan tingkat protein ransum selama periode pertumbuhan terhadap kinerja puyuh petelur. Tesis. Pascasarjana Institut Pertanian Bogor. Bogor.

North, M, O dan Bell, D, D. 1990. Commercial Chicken Production Manual. 4th Ed .Van Nostrand Reinhold. New York.

Nuraini, Sabrina dan S. A. Latif . 2012. Fermented product by Monacus purpureus in poultry diet effects on laying performance and egg quality. Pakistan Journal of Nutrition 11: 507- 510 .

Santos, T. C., A. E. Murakami., J. C. Fanhani, dan C. A. L. Oliveira. 2011. Production and reproduction of egg and meat type Quails reared in different group sizes. Brazilian J. Poultry Sci. 13 (1): 9-14.

Song, K. T., S. H. Choi, dan H. R. Oh. 2000. A comparison of egg quality of pheasant, chukar, quail and guinea fowl. Asian - Aus. J. Anim. Sci. 13 (7): 986-990). 
Steel, R.G.D. dan J.H Torrie, 1994. Prinsip dan Prosedur Statistika Suatu Pendidikan Giometrik, PT. Gramedia Pustaka Utama. Jakarta.

Sumbawati. 1992. Penggunaan beberapa tingkat zeolit dengan tingkat protein dalam ransum burung puyuh terhadap produksi telur, indeks putih telur dan indeks kuning telur.
Sripsi. Fakultas peternakan. Institut Pertanian Bogor. Bogor.

Sunarno. 2004. Potensi Burung Puyuh. Majalah Poultry Indonesia Edisi Februari hal.61.

Yasin, S. 1988. Fungsi dan Peranan Zat- zat Gizi dalam Ransum Ayam Petelur. Mediatama Sarana Perkasa. Mataram. Page 41-43 